\title{
Conditioned place preference and locomotor activity in response to methylphenidate, amphetamine and cocaine in mice lacking dopamine D4 receptors
}

\author{
PK Thanos, \\ Laboratory of Neuroimaging, NIAAA Intramural Program, NIH, Bethesda, MD, USA; Behavioral \\ Pharmacology \& Neuroimaging Lab, Department of Medicine, Brookhaven National Laboratory, \\ Upton, NY, 11973, USA; Department of Psychology; Universidad de Buenos Aires, Buenos Aires, \\ Argentina.
}

\section{Bermeo,}

Behavioral Pharmacology \& Neuroimaging Lab, Department of Medicine, Brookhaven National Laboratory, Upton, NY, 11973, USA.

\section{Rubinstein,}

Universidad de Buenos Aires, Buenos Aires, Argentina.

\section{KL Suchland,}

Department of Physiology and 25 Pharmacology, Oregon Health \& Science University, Portland OR 97239, USA.

\section{GJ Wang,}

Behavioral Pharmacology \& Neuroimaging Lab, Department of Medicine, Brookhaven National Laboratory, Upton, NY, 11973, USA.

DK Grandy, and

Department of Physiology and 25 Pharmacology, Oregon Health \& Science University, Portland OR 97239, USA.

\section{ND Volkow}

Laboratory of Neuroimaging, NIAAA Intramural Program, NIH, Bethesda, MD, USA.

\section{Abstract}

\begin{abstract}
Methylphenidate (MP) and amphetamine (AMPH) are the most frequently prescribed medications for the treatment of attention-deficit/hyperactivity disorder (ADHD). Both drugs are believed to derive their therapeutic benefit by virtue of their dopamine (DA)-enhancing effects, yet an explanation for the observation that some patients with ADHD respond well to one medication but not to the other remains elusive. The dopaminergic effects of MP and AMPH are also thought to underlie their reinforcing properties and ultimately their abuse. Polymorphisms in the human gene that codes for the DA D4 receptor (D4R) have been repeatedly associated with ADHD and may correlate with the therapeutic as well as the reinforcing effects of responses to these psychostimulant medications. Conditioned place preference (CPP) for MP, AMPH and cocaine were evaluated in wild-type (WT) mice and their genetically engineered littermates, congenic on the C57Bl/6J
\end{abstract}

(C) The Author(s), 2009.

Corresponding author: Panayotis K Thanos, Behavioral Pharmacology \& Neuroimaging Lab, Department of Medicine, Brookhaven National Laboratory, Upton, NY, 11973, USA. Email: thanos@bnl.gov; http://www.bnl.gov/thanoslab. 
background, that completely lack D4Rs (knockout or KO). In addition, the locomotor activity in these mice during the conditioning phase of CPP was tested in the CPP chambers. D4 receptor KO and WT mice showed CPP and increased locomotor activity in response to each of the three psychostimulants tested. D4R differentially modulates the CPP responses to MP, AMPH and cocaine. While the D4R genotype affected CPP responses to MP (high dose only) and AMPH (low dose only) it had no effects on cocaine. Inasmuch as CPP is considered an indicator of sensitivity to reinforcing responses to drugs these data suggest a significant but limited role of D4Rs in modulating conditioning responses to MP and AMPH. In the locomotor test, D4 receptor KO mice displayed attenuated increases in AMPH-induced locomotor activity whereas responses to cocaine and MP did not differ. These results suggest distinct mechanisms for D4 receptor modulation of the reinforcing (perhaps via attenuating dopaminergic signalling) and locomotor properties of these stimulant drugs. Thus, individuals with D4 receptor polymorphisms might show enhanced reinforcing responses to $\mathrm{MP}$ and AMPH and attenuated locomotor response to AMPH.

\section{Keywords}

addiction; environment; learning; novelty; psychostimulants; substance abuse

\section{Introduction}

Dopamine (DA) signalling occurs in multiple brain circuits that subserve visual, olfactory, endocrine and behavioural functions. Among the behaviours dependent on DA signalling are locomotion, cognition, motivation, learning and appetite (Missale, et al., 1998; Viggiano, et al., 2003). For scientists investigating the molecular determinants of drug abuse, the involvement of DA signalling in reinforced-based motivation and learning has been of particular interest (Robbins and Everitt, 1996; Wise and Hoffman, 1992).

The DA D4 receptor (D4R) is a D2-like G protein-coupled receptor that is distinguished, in part, by its approximately equal affinity for DA and norepinephrine (NE) (Lanau, et al., 1997; Newman-Tancredi, et al., 1997). In the human population, worldwide, the D4R gene is highly polymorphic in an exon that codes for the protein's third cytoplasmic loop (Ding, et al., 2002; Wang, et al., 2004). The D4R is primarily expressed in the brain, (but is also found outside the brain, such as in the atrial tissue in the heart (Ricci, et al., 1998)), primarily in the prefrontal cortex, dorsal striatum (Ariano, et al., 1997; Avale, et al., 2004; Falzone, et al., 2002; Helmeste and Tang, 2000) and to a lesser extent in hippocampus, nucleus accumbens (Meador-Woodruff, et al., 1994; Mrzljak, et al., 1996) and cerebellum (Ariano, et al., 1997).

In rodents, the $\mathrm{D} 4 \mathrm{R}$ is involved in numerous behaviours including response to novelty and the approach-avoidance response in novelty-related exploration (Paterson, et al., 1999; Shimozato and Watanabe, 2003; Viggiano, et al., 2003). Studies using mice that lack D4Rs (D4R ${ }^{-1-}$ or D4R-knock out (KO)) have revealed that they show a heightened sensitivity to open-field locomotor tests when treated with different abused drugs including ethanol, cocaine, amphetamine (AMPH), methamphetamine and methylphenidate (MP) (Kruzich, et al., 2004; Rubinstein, et al., 1997). These mice also exhibit reduced behavioural responses to novelty in the open field and to novel objects compared with wild-type (D4R ${ }^{+/+}$, D4R-WT) littermates (Dulawa, et al., 1999). C57Bl/6J mice that completely lack the D4R also show enhanced behavioural responses to unconditioned fear, a result that has led some to hypothesise that in humans D4R-mediated signalling in the brain contributes to an individual's response to stressful and/or anxiety producing stimuli (Falzone, et al., 2002). Additionally, the D4R-KO mouse has been proposed as a mouse model of attention-deficit/hyperactivity disorder (ADHD) (Avale, et al., 2004). 
Polymorphisms in the human DRD4 gene have been repeatedly associated with ADHD (Falzone, et al., 2002; Grady, et al., 2003; LaHoste, et al., 1996; Swanson, et al., 1998). Specifically, the DRD4 alleles containing a sequence tandemly repeated seven times (rather than four times as is the case for the common variant) in exon III is associated with an increased risk for ADHD (Faraone, et al., 2005; Li, et al., 2006) and interestingly, might be predictive of an individual's response to MP (McGough, et al., 2006).

Although the DA system and the D4R in particular are implicated in ADHD, it is important to point out that MP and AMPH, the two most frequently used drugs in the treatment of ADHD, enhance both DA and NE in the brain (Castellanos and Tannock, 2002; DiMaio, et al., 2003). MP increases DA and NE by blocking the DA transporter (DAT) and the NE (NET) transporter, respectively (Kuczenski and Segal, 1997; Meririnne, et al., 2001), whereas AMPH increases DA, NE and serotonin (5-HT) by releasing these neurotransmitters from intracellular stores via their respective transporters (Sulzer, et al., 2005). Both MP and AMPH have reinforcing effects in laboratory animals (Hoebel, et al., 1983; Nielsen, et al., 1984; Yokel and Wise, 1978) and in humans (de Wit, et al., 1986; 1987; Gatley, et al., 1999; Sulzer, et al., 2005; Volkow, 2006; Volkow, et al., 2001; Volkow, et al., 2004); though most of these clinical reports are subjective evaluations assessed by verbal report. Their reinforcing properties likely reflect their ability to rapidly increase extracellular DA (Volkow, et al., 2004). Indeed, MP and AMPH can be diverted and abused (Gordon, et al., 2004; Parran and Jasinski, 1991; Rush, et al., 2001; Volkow, 2006).

Cocaine-like MP and AMPH is a potent psychostimulant but differs in that it also has local anaesthetic properties (Bernards, 1996; Du, et al., 2006). Cocaine-like MP increases DA and NE (but different from MP increases 5-HT) by blocking DAT and NET (different from MP also blocks 5-HT transporters) (Filip, et al., 2005; Hall, et al., 2002; Hall, et al., 2004).

These three psychostimulant drugs induce strong conditioned place preference (CPP) in rodents (Belzung and Barreau, 2000; Meririnne, et al., 2001; Zhang, et al., 2002). DA D2 receptors (D2Rs) are involved in CPP since D2R antagonists interfere with its expression (Aujla and Beninger, 2005; Cervo, et al., 2005; Cunningham, et al., 2000; Gilbert, et al., 2005; Le Foll, et al., 2005; Rezayof, et al., 2002). The role of DA D4R in CPP has been difficult to evaluate due to the lack of specific D4R antagonists drugs. In this respect, KO mice offer an alternative strategy to assess the involvement of a particular receptor on behavioural responses to drugs.

Here, we used the D4R-KO mouse model to evaluate the role of D4R in stimulant-induced CPP and how this related to stimulant-induced locomotor activation in the CPP chamber (during the conditioning phase). The involvement of D4R in CPP to cocaine, MP and AMPH during a CPP experiment has not been determined and while the effects of these drugs on locomotor activity has been evaluated in open-field chamber, the locomotor responses in the CPP chambers have not been studied.

\section{Materials and methods}

\section{Subjects}

Adolescent (4-6-week-old) male ( $\sim 20-25 \mathrm{~g}$ ) mice (see experiments below for sample size), congenic (i.e. backcrossed onto inbred $\mathrm{C} 57 \mathrm{Bl} / 6 \mathrm{~J}$ mice for more than 10 generations), were derived from mating D4R heterozygotes (129/OlaxC57B1/6J) as previously described (Rubinstein, et al., 1997) were used in this study. Animals were housed under standard conditions with ambient temperature $\left(72 \pm 2^{\circ} \mathrm{F}\right)$ and humidity $(40-60 \%)$ controlled. After weaning, mice were individually housed and kept on a reversed 12:12 dark/light cycle with lights off at 08:00 h. Both food and water were available at all times, except during testing. 
Procedures were approved by the Institutional Animal Care and Use Committee of Brookhaven National Laboratory, USA.

\section{Apparatus}

The CPP apparatus (Habitest - Coulbourn Instruments, Allentown, PA) composed of two compartments $(30.5 \mathrm{~cm}$ length $\times 26.5 \mathrm{~cm}$ width $\times 37 \mathrm{~cm}$ height $)$ that were connected by a central corridor ( $12.75 \mathrm{~cm}$ length $\times 23 \mathrm{~cm}$ width $\times 15.25 \mathrm{~cm}$ height). The compartment on the left had a black wall colour with a perforated stainless steel floor with round holes on staggered centres, the central corridor was transparent with a smooth plexi-glass floor and the left compartment had a white wall colour with a stainless steel mesh floor. Four infrared beams were used to assess the animal's location and time spent in each location from which preference was calculated. In addition, locomotor activity during CPP was measured by two infrared activity monitors mounted on the ceilings of CPP chambers (black and white compartments); each movement made by the animal was counted as a beam break. The infrared beams were connected to a computer and data were acquired with Graphic State version II software (Coulbourn Instruments). Mean locomotor activity was calculated for each mouse across each treatment (averaging all drug or saline treatments) during the conditioning phase of the CPP study (see below).

\section{Procedure: CPP and locomotor activity}

The procedure of this study is outlined in the timeline presented in Figure 1. Specifically, the procedures include the following phases.

Pre-conditioning phase-On day 1 , all mice were placed in the centre corridor; the automated sliding doors leading to both compartments were then opened giving the animal free access to both compartments for a total of 15 minutes. During this period, locomotor activity (measured in beam breaks) and the time spent in each compartment (measured in milliseconds) were calculated. Animals remained in the pre-conditioning phase until they exhibited no preference for either compartment or after four sessions (one session was run per day). If at that point a mouse had a preference for a particular compartment, then it received the drug in the opposite compartment. Generally, the majority of mice did not show any preference on day 1 during the pre-conditioning stage, and all mice showed no preference after 2 days of pre-conditioning.

Conditioning phase-On day 2 , the mice where randomly assigned to receive four drugpaired sessions in one compartment and four saline-paired sessions in the opposite compartment on alternate days (see Figure 1). This phase took place over a period of 8 days, and each session was for 40 minutes. Locomotor activity (measured in beam breaks) was assessed daily in this phase for both the drug and saline sessions.

Test day-On day 10, the subjects were placed in the centre corridor where they had access to both black and white compartments for a total of 15 minutes (Figure 1). Total \% preference was assessed for each of the two compartments by measuring the time spent in each compartment (measured in milliseconds) divided by the total time in all compartments.

\section{Drugs}

MP (racemic), d-amphetamine sulphate (AMPH) and cocaine hydrochloride, were purchased from Sigma-Aldrich (St. Louis, MO, USA). The drugs were intraperitoneally (i.p.) administered at 1 and $3 \mathrm{mg} / \mathrm{kg}$ (MP and AMPH) and 1 and $4 \mathrm{mg} / \mathrm{kg}$ (cocaine). Drugs were dissolved in an isotonic saline solution $(0.9 \% \mathrm{NaCl})$ and administered in a volume of $1 \mathrm{~mL}$ per $100 \mathrm{~g}$ of body weight. 


\section{Experiments}

Experiment 1: MP-Mice were randomly assigned into groups within respective strains and genotypes. Mutant mice were administered $1 \mathrm{mg} / \mathrm{kg}\left[\left(\mathrm{D}^{2} \mathrm{R}^{-/-}\right) n=11,\left(\mathrm{D}^{2} \mathrm{R}^{+/-}\right) n=12\right.$ and $\left.\left.\left(\mathrm{D} 4 \mathrm{R}^{+/+}\right) n=12\right)\right]$ or $3 \mathrm{mg} / \mathrm{kg}\left[\left(\mathrm{D} \mathrm{R}^{-/-}\right) n=11,\left(\mathrm{D} 4 \mathrm{R}^{+/-}\right) n=12\right.$ and $\left.\left.\left(\mathrm{D}^{2} \mathrm{R}^{+/+}\right) n=12\right)\right]$ of MP during the drug days of the conditioning session; and saline, as a vehicle.

Experiment 2: AMPH—As in Experiment 1, mice were randomly assigned into groups, within respective strains and genotypes. Mice were administered $1 \mathrm{mg} / \mathrm{kg}\left[\left(\mathrm{D} 4 \mathrm{R}^{-/-}\right) n=11\right.$, $\left(\mathrm{D} 4 \mathrm{R}^{+/-}\right) n=12$ and $\left.\left.\left(\mathrm{D} 4 \mathrm{R}^{+/+}\right) n=12\right)\right]$ or $3 \mathrm{mg} / \mathrm{kg}\left[\left(\mathrm{D} 4 \mathrm{R}^{-/-}\right) n=10,\left(\mathrm{D} 4 \mathrm{R}^{+/-}\right) n=11\right.$ and $\left.\left(\mathrm{D} 4 \mathrm{R}^{+/+}\right) n=11\right)$ ] of AMPH during the drug days of the conditioning session; and saline, as a vehicle.

Experiment 3: Cocaine-Similarly, mice were administered $1 \mathrm{mg} / \mathrm{kg}\left[\left(\mathrm{D} 4 \mathrm{R}^{-/-}\right) n=12\right.$,

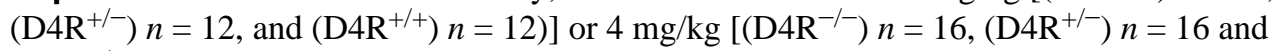
$\left.\left(\mathrm{D} 4 \mathrm{R}^{+/+}\right) n=16\right]$ during the drug days of the conditioning session; and saline, as a vehicle.

\section{Statistical analysis}

A two-way analysis of variance (ANOVA, followed by pair-wise comparisons using the HolmSidak method) was used in the analysis of both the CPP and locomotor activity data for both genotype and treatment as the variables. All statistical comparisons were performed using the SigmaStat 3.1 statistical software.

\section{Results CPP}

Experiment 1: MP-CPP for MP was evaluated using a two-way ANOVA. A significant treatment effect was observed $[\mathrm{F}(2,97)=25.41 ; P<0.001$; Figure 2] while genotype was not $[\mathrm{F}(2,97)=0.94 ; P>0.05]$. The genotype by treatment interaction was significant $[\mathrm{F}(4,97)=$ $2.48 ; P<0.05]$.

Pair-wise multiple comparisons between saline and MP were performed within genotype (Figure 2) revealed the following: A) $\mathbf{D} 4 \mathbf{R}^{+/+}$mice showed significant CPP in response to 1 $\mathrm{mg} / \mathrm{kg} \mathrm{MP}(\mathrm{t}=4.68 ; P<0.001)$ and $3 \mathrm{mg} / \mathrm{kg} \mathrm{MP}(\mathrm{t}=5.08 ; P<0.001)$. B $) \mathbf{D}^{4} \mathbf{R}^{+/-}$mice produced significant CPP to $1 \mathrm{mg} / \mathrm{kg}(\mathrm{t}=2.23 ; P<0.05)$ and $3 \mathrm{mg} / \mathrm{kg} \mathrm{MP}(\mathrm{t}=3.83 ; P<0.001)$. C) Similarly, D4R ${ }^{-/-}$mice showed CPP to $1 \mathrm{mg} / \mathrm{kg}$ MP $(\mathrm{t}=3.14 ; P<0.01)$ and $3 \mathrm{mg} / \mathrm{kg} \mathrm{MP}(\mathrm{t}$ $=7.33 ; P<0.001)$; and the preference to the $3 \mathrm{mg} / \mathrm{kg} \mathrm{MP}$ was greater than that at $1 \mathrm{mg} / \mathrm{kg} \mathrm{MP}$ $(\mathrm{t}=3.493 ; P<0.001)$. Pair-wise comparisons across genotypes within saline and $1 \mathrm{mg} / \mathrm{kg} \mathrm{MP}$ revealed no differences $(P>0.05)$. However, there was a difference at $3 \mathrm{mg} / \mathrm{kg} \mathrm{MP}$, where $\mathrm{D} 4^{-/-}$mice showed significantly greater CPP than $\mathbf{D 4} \mathbf{R}^{+/-}$mice $(\mathrm{t}=2.04 ; P<0.05)$ and a trend (not significant) toward greater CPP than the $\mathbf{D} 4 \mathbf{R}^{+/+}$mice $(\mathrm{t}=1.77 ; P=0.08)$.

Experiment 2: AMPH-A two-way ANOVA with treatment and genotype as main factors revealed no significant genotype effect $[\mathrm{F}(2,97)=0.070 ; P>0.05$; Figure 2], a significant treatment effect $[\mathrm{F}(2,97)=95.685 ; P<0.05]$ and a significant treatment by genotype interaction $[\mathrm{F}(4,97)=2.67 ; P<0.05]$.

Pair-wise multiple comparisons (Figure 2) revealed that $\mathbf{D 4} \mathbf{R}^{+/+}$mice showed significant CPP to $1 \mathrm{mg} / \mathrm{kg}(\mathrm{t}=4.69 ; P<0.001)$ and $3 \mathrm{mg} / \mathrm{kg}, \mathrm{AMPH}(\mathrm{t}=7.42 ; P<0.001)$ and a significant difference in CPP between the two doses $(\mathrm{t}=2.37 ; \mathrm{P}<0.01)$. The $\mathbf{D} 4 \mathbf{R}^{-/+}$mice showed significant CPP to both $1(\mathrm{t}=6.67 ; P<0.001)$ and $3 \mathrm{mg} / \mathrm{kg}$ AMPH $(\mathrm{t}=6.14 ; P<0.001)$. Similarly, D4R ${ }^{-I}$ mice showed CPP to both $1(\mathrm{t}=8.11 ; P<0.001)$ and $3 \mathrm{mg} / \mathrm{kg} \mathrm{MP}(\mathrm{t}=6.03$; 
$P<0.001)$. Comparisons between genotypes within treatments revealed significant differences in CPP D4R $\mathbf{R}^{+/+}<$D4R $\mathbf{R}^{-/-}$mice $(\mathrm{t}=2.670, P<0.001)$ for the $1 \mathrm{mg} / \mathrm{kg}$ AMPH.

Experiment 3: Cocaine-CPP to 1 and $4 \mathrm{mg} / \mathrm{kg}$ cocaine was evaluated using a two-way ANOVA (Figure 2) and a significant treatment effect was observed $[\mathrm{F}(2,97)=33.30 ; P<$ $0.001]$. Neither, the genotype $[\mathrm{F}(2,97)=0.08 ; P>0.05]$ nor the genotype by treatment interaction effects were significant $[\mathrm{F}(4,97)=0.85 ; P>0.05]$. Pair-wise multiple comparisons revealed that cocaine CPP was greater in response to $4 \mathrm{mg} / \mathrm{kg}(\mathrm{t}=8.0 ; P<0.001)$ than $1 \mathrm{mg} /$ kg cocaine $(\mathrm{t}=5.53 ; P<0.001)$.

\section{Locomotor activity}

Experiment 1: MP-A two-way ANOVA revealed a significant effect of MP treatment on locomotor activity $[\mathrm{F}(2,97)=18.22 ; P<0.001]$ but no effect of genotype $[\mathrm{F}(2,97)=0.22$; $P>0.05]$ or genotype by treatment interaction $[\mathrm{F}(4,97)=0.14 ; P>0.05]$ (Figure 3). Pair-wise comparisons revealed that the locomotor activity in all three genotypes was increased following $3 \mathrm{mg} / \mathrm{kg}$ MP in comparison to saline $(\mathrm{t}=6.682 ; P<0.001)$, but no effect following $1 \mathrm{mg} / \mathrm{kg}$ MP. Locomotor activity was significantly greater across all genotypes at $3 \mathrm{mg} / \mathrm{kg}$ than with 1 $\mathrm{mg} / \mathrm{kg} \mathrm{MP}(\mathrm{t}=4.326 ; P<0.001)$.

Experiment 2: AMPH—A similar ANOVA revealed a significant effect of AMPH on locomotor activity $[\mathrm{F}(2,97)=30.27 ; P<0.001 ;$ Figure 3$]$, no effect of genotype $[\mathrm{F}(2,97)=$ $0.42 ; P>0.05]$, but a significant genotype by treatment interaction $[\mathrm{F}(4,97)=3.09 ; P<0.02]$. Pair-wise comparisons of $\mathbf{D} 4 \mathbf{R}^{+/+}$mice revealed that $1(\mathrm{t}=3.42 ; P<0.001)$ and $3 \mathrm{mg} / \mathrm{kg}$ AMPH $(\mathrm{t}=3.2 ; P<0.01)$ increased locomotor activity. $\mathbf{D} 4 \mathbf{R}^{-/+}$mice showed that $3 \mathrm{mg} / \mathrm{kg}$ AMPH had a stimulatory effect $(\mathrm{t}=5.86 ; P<0.01)$ as compared with $1 \mathrm{mg} / \mathrm{kg}$ AMPH $(\mathrm{t}=3.87 ; P<$ $0.001)$. D4R $\mathbf{R}^{-/-}$mice revealed similar differences as in HT mice where only $3 \mathrm{mg} / \mathrm{kg}$ AMPH produced more locomotion than saline $(\mathrm{t}=4.41 ; P<0.001)$. Finally, $1 \mathrm{mg} / \mathrm{kg}$ AMPH showed a significant increase in locomotor activity in the $\mathbf{D} 4 \mathbf{R}^{+/+}$mice compared with both $\mathbf{D} 4 \mathbf{R}^{-/+}$ and the $\mathbf{D} 4 \mathbf{R}^{-/-}$mice $(\mathrm{t}=2.51 ; P<0.01$; Figure 3$)$.

Experiment 3: Cocaine-A two-way ANOVA revealed a significant treatment effect of cocaine $[\mathrm{F}(2,110)=3.87 ; P<0.05$; Figure 3$]$ that was not influenced by genotype $[\mathrm{F}(2,110)$ $=0.55 ; P>0.05]$ or treatment by genotype interaction $(P>0.05)$. Pair-wise comparisons showed that $4 \mathrm{mg} / \mathrm{kg}$ cocaine treated mice showed greater locomotor activity compared with both saline $(\mathrm{t}=2.49 ; P<0.01)$ and $1 \mathrm{mg} / \mathrm{kg}$ cocaine $(\mathrm{t}=2.35 ; P<0.05)$.

\section{Discussion}

These experiments revealed that the D4R differentially modulates the CPP responses to MP, AMPH and cocaine. Although the D4R genotype affected CPP responses to MP (high dose only) and AMPH (low dose only), it had no effects on cocaine. Inasmuch as CPP is considered an indicator of sensitivity to reinforcing responses to drugs, these data suggest a significant but limited role of D4Rs in modulating conditioning responses to MP and AMPH.

In contrast, locomotor activity in the CPP compartment to MP, AMPH and cocaine was similar across genotypes; except for an attenuated response in $\mathrm{KO}$ to the $1 \mathrm{mg} / \mathrm{kg}$ i.p. AMPH dose relative to WT mice. These findings contrast with the enhanced locomotor sensitivity reported by D4R-KO mice to locomotor activity when tested in an open-field chamber (Katz, et al., 2003; Rubinstein, et al., 1997). 


\section{CPP}

All genotypes revealed significantly greater CPP for the MP-paired versus the saline-paired compartments. This was consistent with previous studies showing MP CPP in rats at doses of $1 \mathrm{mg} / \mathrm{kg}$ or greater (Gatley, et al., 1996; Martin-Iverson, et al., 1985; Meririnne, et al., 2001; Mithani, et al., 1986). Although WT showed slightly greater CPP to the $1 \mathrm{mg} / \mathrm{kg}$ MP than HT and $\mathrm{KO}$ mice, this was not statistically significant. However, the CPP response to the $3 \mathrm{mg} / \mathrm{kg}$ MP dose was greater for KO ( 65\%) than HT mice and showed a trend for WT $(P<0.08)$. This suggests that D4R may modulate the sensitivity to the conditioning effects of MP. Thus, decreased levels of the D4R may be expected to enhance or potentiate the conditioning effects of MP, which are markers for reinforcement.

AMPH ( 1 and $3 \mathrm{mg} / \mathrm{kg}$ ) produced significant CPP for all mice relative to saline. Comparison across genotypes revealed a statistical difference in CPP between the WT and KO mice for the $1 \mathrm{mg} / \mathrm{kg}$ but not for the $3 \mathrm{mg} / \mathrm{kg}$ dose of AMPH. At the lower dose, KO mice showed significantly greater CPP $(\sim 65 \%)$ than WT mice $(\sim 55 \%)$.

AMPH increases DA, NE and 5-HT in the brain by stimulating their release. Previous research has suggested that D4 receptors are activated by DA, NE and epinephrine (Czermak, et al., 2006). This D4R affinity to NE and epinephrine was found to be unique (Czermak, et al., 2006; Newman-Tancredi, et al., 1997; Wedemeyer, et al., 2007). Thus a deficiency in D4Rs may impact signalling mediated via $\mathrm{NE}$ and may help explain to some degree the differences in AMPH CPP at the $1 \mathrm{mg} / \mathrm{kg}$ dose.

The observed CPP effects of AMPH and MP could help provide some insight into the mechanisms of action of these drugs. AMPH releases DA from the terminals independent of DA cell firing, whereas MP (DAT blocker) increases DA that is dependent on DA cell firing. Also, AMPH, unlike MP, increases extra-cellular 5-HT which is particularly relevant since D4R-deficient mice may have adaptations in 5-HT neurotransmission (Han and Gu, 2006). However, since we observed similar pattern of CPP effects to both MP and AMPH (greater $\mathrm{CPP}$ in D4R KO), this suggests that 5-HT is not modulating the enhanced sensitivity to CPP in $\mathrm{D} 4 \mathrm{R}-\mathrm{KO}$ mice.

Cocaine like MP, blocks DAT inhibiting the removal of DA from the synaptic cleft and this effect is associated with its reinforcing effects. Cocaine inhibits DAT, NET and 5-HT transporters within a narrow concentration range, suggesting that modulation of all three neurotransmitter systems are likely to contribute to its pharmacological effects (Han and $\mathrm{Gu}$, 2006). In all mice, cocaine produced CPP with the high (4 mg/kg cocaine) but not the low dose $(1 \mathrm{mg} / \mathrm{kg})$. All three groups regardless of genotype showed similar cocaine CPP as previously reported in different mouse strains ((Swiss Webster; C57BL/6J -4-20 mg/kg cocaine (Brabant, et al., 2005a; Brabant, et al., 2005b; Itzhak and Martin, 2002)).

\section{Locomotor activity}

MP induced a dose dependent increase in locomotor activation during the CPP conditioning phase across all mice tested irrespective of their genotype. These results were consistent with open-field locomotor activity findings in Swiss Webster (Gatley, et al., 1999) and C57BL/6 (Williard, et al., 2007) mice.

D4R influenced AMPH but not MP-induced locomotor activity during conditioning. Although WT responded to both doses of AMPH, HT and KO did not respond to the $1 \mathrm{mg} / \mathrm{kg}$ AMPH dose, whereas their response to the $3 \mathrm{mg} / \mathrm{kg}$ dose of AMPH was greater than that of WT. These data corroborate the role of D4R in the locomotor properties of AMPH. Specifically, these findings are consistent with those reported using a different paradigm (open-field locomotor activity) that showed that D4R-KO mice tended to have enhanced motor activation following 
3 and $10 \mathrm{mg} / \mathrm{kg}$ AMPH though these differences were not significant (Kruzich, et al., 2004). The later study also reported that D4R-KO mice showed enhanced sensitization to AMPH (Kruzich, et al., 2004). The lack of an effect of D4R in the locomotor responses to MP and the enhanced responses to the high dose of AMPH suggests that this modulation is mediated through 5-HT. Indeed prior studies have shown that the locomotor activating effects of MP are enhanced by serotonin agonists an effect that is mediated by 5-HT 1B receptors (Borycz, et al., 2008).

Cocaine dose-dependently increased locomotor activation in all mice during the CPP conditioning phase regardless of D4R genotype. Previous studies reported that higher doses of cocaine $(15 \mathrm{mg} / \mathrm{kg}$ and $30 \mathrm{mg} / \mathrm{kg}$ i.p.) stimulated open-field locomotor activity in the D4R$\mathrm{KO}$ and that $\mathrm{KO}$ were supersensitive to the stimulating properties of cocaine (Katz, et al., 2003; Rubinstein, et al., 1997). Although the present findings did not show this cocaine hypersensitivity in $\mathrm{KO}$ mice, this may reflect the fact that we used much smaller cocaine doses ( $4 \mathrm{mg} / \mathrm{kg}$ ) as compared with $15 \mathrm{mg}$ and $30 \mathrm{mg} / \mathrm{kg}$ doses used by studies that reported hypersensitivity. This is plausible since the hypersensitivity to the locomotor effects of AMPH, which like cocaine increases 5-HT was observed only for the higher dose $(3 \mathrm{mg} / \mathrm{kg})$ but not the low dose of AMPH $(1 \mathrm{mg} / \mathrm{kg})$. Although AMPH is more potent than cocaine in increasing 5-HT, this suggests that the high dose of cocaine may have been too low to compare with the effects of AMPH $(3 \mathrm{mg} / \mathrm{kg})$. Evidence that this was the case is provided by microdialysis studies showing that $5 \mathrm{mg} / \mathrm{kg}$ i.p. cocaine does not increase serotonin in the brain, whereas $3 \mathrm{mg}$ of AMPH significantly increased serotonin whereas a $1 \mathrm{mg} / \mathrm{kg}$ AMPH dose had minimal effects (Pum, et al., 2007). However it is also plausible that differences in the paradigm also contributed to these discrepancies (locomotor activity measured in CPP chamber rather than an open-field chamber).

\section{Summary}

Although it is commonly accepted that MP, AMPH and cocaine exert their effect primarily through the DA system, the involvement of NE and 5-HT systems in this mechanism of action is also important. The role of the D4R in modulating reward or conditioning (CPP) and locomotor properties during conditioning of these stimulant drugs has not been previously determined. In the present study, D4R was shown to have limited impact on mouse behaviour response to these drugs. However, some small but significant differences were observed. Specifically, D4R-KO mice showed an enhanced CPP to the high dose of MP $(3 \mathrm{mg} / \mathrm{kg})$ and the low dose of AMPH $(1 \mathrm{mg} / \mathrm{kg})$ but no differences in CPP cocaine. However, the failure to reveal a difference in CPP to cocaine may have reflected the relatively low dose we used rather than a differential response to this stimulant drug.

We also document a blunted response to the locomotor activating effects of the $1 \mathrm{mg} / \mathrm{kg}$ i.p. dose of AMPH in D4R-KO mice, whereas the response to the higher dose was enhanced; and there were no differences in responses to MP or cocaine. The lack of an effect of MP and of cocaine (doses used were too low to increase serotonin) is likely to suggest that serotonergic effects may mediate the differences in sensitivity to the locomotor effects of the D4R-KO mice. Indeed, it could be postulated that serotonergic adaptation in D4R-KO may compensate for the decreased sensitivity to DA stimulation.

Although CPP serves as a surrogate marker to the reinforcing effects of drugs, the enhanced CPP responses in the D4R-KO mice suggest that the seven repeat allele for the D4R gene (which confers decreased sensitivity to DA), may be associated with an enhanced sensitivity to the conditioning effects of stimulant drugs. Future studies examining self-administration in D4R mice are necessary to assess the role of D4R in modulating the incentive motivation to administer psychostimulant drugs. 


\section{Acknowledgments}

This work was supported by NIMH (MH67497 to DKG), the NIAAA Intramural Research Program (AA 11034 \& AA07574, AA07611) and by the U.S. Department of Energy under contract DE-AC02. CB was partially funded by the DOE SULI summer research program.

\section{References}

Ariano MA, Wang J, Noblett KL, Larson ER, Sibley DR. Cellular distribution of the rat D4 dopamine receptor protein in the CNS using anti-receptor antisera. Brain Res 1997;752:26-34. [PubMed: 9106437]

Aujla H, Beninger RJ. The dopamine D(3) receptor-preferring partial agonist BP 897 dose-dependently attenuates the expression of amphetamine-conditioned place preference in rats. Behav Pharmacol 2005;16:181-186. [PubMed: 15864073]

Avale ME, Falzone TL, Gelman DM, Low MJ, Grandy DK, Rubinstein M. The dopamine D4 receptor is essential for hyperactivity and impaired behavioral inhibition in a mouse model of attention deficit/ hyperactivity disorder. Mol Psychiatry 2004;9:718-726. [PubMed: 14699433]

Belzung C, Barreau S. Differences in drug-induced place conditioning between BALB/c and C57B1/6 mice. Pharmacol Biochem Behav 2000;65:419-423. [PubMed: 10683481]

Bernards CM. Centrally mediated hemodynamic effects of cocaine in rabbits: the role of local anesthetic actions and biogenic amine re-uptake blockage. Eur J Pharmacol 1996;307:33-39. [PubMed: 8831101]

Borycz J, Zapata A, Quiroz C, Volkow ND, Ferre S. 5-HT 1B receptor-mediated serotoninergic modulation of methylphenidate-induced locomotor activation in rats. Neuropsychopharmacology 2008;33:619-626. [PubMed: 17487226]

Brabant C, Charlier Y, Quertemont E, Tirelli E. The H3 antagonist thioperamide reveals conditioned preference for a context associated with an inactive small dose of cocaine in C57BL/6J mice. Behav Brain Res 2005a;160:161-168. [PubMed: 15836911]

Brabant C, Quertemont E, Tirelli E. Evidence that the relations between novelty-induced activity, locomotor stimulation and place preference induced by cocaine qualitatively depend upon the dose: a multiple regression analysis in inbred C57BL/6J mice. Behav Brain Res 2005b;158:201-210. [PubMed: 15698886]

Castellanos FX, Tannock R. Neuroscience of attention-deficit/hyperactivity disorder: the search for endophenotypes. Nat Rev Neurosci 2002;3:617-628. [PubMed: 12154363]

Cervo L, Burbassi S, Colovic M, Caccia S. Selective antagonist at D3 receptors, but not non-selective partial agonists, influences the expression of cocaine-induced conditioned place preference in freefeeding rats. Pharmacol Biochem Behav 2005;82:727-734. [PubMed: 16405981]

Cunningham CL, Howard MA, Gill SJ, Rubinstein M, Low MJ, Grandy DK. Ethanol-conditioned place preference is reduced in dopamine D2 receptor-deficient mice. Pharmacol Biochem Behav 2000;67:693-699. [PubMed: 11166059]

Czermak C, Lehofer M, Liebmann PM, Traynor J. [35S] GTPgammaS binding at the human dopamine D4 receptor variants hD4.2, hD4.4 and hD4.7 following stimulation by dopamine, epinephrine and norepinephrine. Eur J Pharmacol 2006;531:20-24. [PubMed: 16423344]

de Wit H, Uhlenhuth EH, Johanson CE. Individual differences in the reinforcing and subjective effects of amphetamine and diazepam. Drug Alcohol Depend 1986;16:341-360. [PubMed: 3698813]

de Wit $\mathrm{H}$, Uhlenhuth $\mathrm{EH}$, Johanson CE. The reinforcing properties of amphetamine in overweight subjects and subjects with depression. Clin Pharmacol Ther 1987;42:127-136. [PubMed: 3608346]

DiMaio S, Grizenko N, Joober R. Dopamine genes and attention-deficit hyperactivity disorder: a review. J Psychiatry Neurosci 2003;28:27-38. [PubMed: 12587848]

Ding YC, Chi HC, Grady DL, Morishima A, Kidd JR, Kidd KK, et al. Evidence of positive selection acting at the human dopamine receptor D4 gene locus. Proc Natl Acad Sci U S A 2002;99:309-314. [PubMed: 11756666]

Du C, Yu M, Volkow ND, Koretsky AP, Fowler JS, Benveniste H. Cocaine increases the intracellular calcium concentration in brain independently of its cerebrovascular effects. J Neurosci 2006;26:11522-11531. [PubMed: 17093073] 
Dulawa SC, Grandy DK, Low MJ, Paulus MP, Geyer MA. Dopamine D4 receptor-knock-out mice exhibit reduced exploration of novel stimuli. J Neurosci 1999;19:9550-9556. [PubMed: 10531457]

Falzone TL, Gelman DM, Young JI, Grandy DK, Low MJ, Rubinstein M. Absence of dopamine D4 receptors results in enhanced reactivity to unconditioned, but not conditioned, fear. Eur J Neurosci 2002;15:158-164. [PubMed: 11860516]

Faraone SV, Perlis RH, Doyle AE, Smoller JW, Goralnick JJ, Holmgren MA, et al. Molecular genetics of attention-deficit/hyperactivity disorder. Biol Psychiatry 2005;57:1313-1323. [PubMed: 15950004]

Filip M, Frankowska M, Zaniewska M, Golda A, Przegalinski E. The serotonergic system and its role in cocaine addiction. Pharmacol Rep 2005;57:685-700. [PubMed: 16382187]

Gatley SJ, Meehan SM, Chen R, Pan DF, Schechter MD, Dewey SL. Place preference and microdialysis studies with two derivatives of methylphenidate. Life Sci 1996;58:PL345-PL352. [PubMed: 8649202]

Gatley SJ, Volkow ND, Gifford AN, Fowler JS, Dewey SL, Ding YS, et al. Dopamine-transporter occupancy after intravenous doses of cocaine and methylphenidate in mice and humans. Psychopharmacology (Berl) 1999;146:93-100. [PubMed: 10485970]

Gilbert JG, Newman AH, Gardner EL, Ashby CR Jr, Heidbreder CA, Pak AC, et al. Acute administration of SB-277011A, NGB 2904, or BP 897 inhibits cocaine cue-induced reinstatement of drug-seeking behavior in rats: role of dopamine D3 receptors. Synapse 2005;57:17-28. [PubMed: 15858839]

Gordon SM, Tulak F, Troncale J. Prevalence and characteristics of adolescents patients with co-occurring ADHD and substance dependence. J Addict Dis 2004;23:31-40. [PubMed: 15339712]

Grady DL, Chi HC, Ding YC, Smith M, Wang E, Schuck S, et al. High prevalence of rare dopamine receptor D4 alleles in children diagnosed with attention-deficit hyperactivity disorder. Mol Psychiatry 2003;8:536-545. [PubMed: 12808433]

Hall FS, Li XF, Sora I, Xu F, Caron M, Lesch KP, et al. Cocaine mechanisms: enhanced cocaine, fluoxetine and nisoxetine place preferences following monoamine transporter deletions. Neuroscience 2002;115:153-161. [PubMed: 12401330]

Hall FS, Sora I, Drgonova J, Li XF, Goeb M, Uhl GR. Molecular mechanisms underlying the rewarding effects of cocaine. Ann N Y Acad Sci 2004;1025:47-56. [PubMed: 15542699]

Han DD, Gu HH. Comparison of the monoamine transporters from human and mouse in their sensitivities to psychostimulant drugs. BMC Pharmacol 2006;6:2210-2216.

Helmeste DM, Tang SW. Dopamine D4 receptors. Jpn J Pharmacol 2000;82:1-14. [PubMed: 10874582]

Hoebel BG, Monaco AP, Hernandez L, Aulisi EF, Stanley BG, Lenard L. Self-injection of amphetamine directly into the brain. Psychopharmacology (Berl) 1983;81:158-163. [PubMed: 6415748]

Itzhak Y, Martin JL. Cocaine-induced conditioned place preference in mice: induction, extinction and reinstatement by related psychostimulants. Neuropsychopharmacology 2002;26:130-134. [PubMed: 11751040]

Katz JL, Chausmer AL, Elmer GI, Rubinstein M, Low MJ, Grandy DK. Cocaine-induced locomotor activity and cocaine discrimination in dopamine D4 receptor mutant mice. Psychopharmacology (Berl) 2003;170:108-114. [PubMed: 12783155]

Kruzich PJ, Suchland KL, Grandy DK. Dopamine D4 receptor-deficient mice, congenic on the C57BL/ $6 \mathrm{~J}$ background, are hypersensitive to amphetamine. Synapse 2004;53:131-139. [PubMed: 15170825]

Kuczenski R, Segal DS. Effects of methylphenidate on extra-cellular dopamine, serotonin, and norepinephrine: comparison with amphetamine. J Neurochem 1997;68:2032-2037. [PubMed: 9109529]

LaHoste GJ, Swanson JM, Wigal SB, Glabe C, Wigal T, King N, et al. Dopamine D4 receptor gene polymorphism is associated with attention deficit hyperactivity disorder. Mol Psychiatry 1996;1:121-124. [PubMed: 9118321]

Lanau F, Zenner MT, Civelli O, Hartman DS. Epinephrine and norepinephrine act as potent agonists at the recombinant human dopamine D4 receptor. J Neurochem 1997;68:804-812. [PubMed: 9003072]

Le Foll B, Sokoloff P, Stark H, Goldberg SR. Dopamine D3 receptor ligands block nicotine-induced conditioned place preferences through a mechanism that does not involve discriminative-stimulus or antidepressant-like effects. Neuropsychopharmacology 2005;30:720-730. [PubMed: 15562293] 
Li D, Sham PC, Owen MJ, He L. Meta-analysis shows significant association between dopamine system genes and attention deficit hyperactivity disorder (ADHD). Hum Mol Genet 2006;15:2276-2284. [PubMed: 16774975]

Martin-Iverson MT, Ortmann R, Fibiger HC. Place preference conditioning with methylphenidate and nomifensine. Brain Res 1985;332:59-67. [PubMed: 3922561]

McGough J, McCracken J, Swanson J, Riddle M, Kollins S, Greenhill L, et al. Pharmacogenetics of methylphenidate response in preschoolers with ADHD. J Am Acad Child Adolesc Psychiatry 2006;45:1314-1322. [PubMed: 17023870]

Meador-Woodruff JH, Grandy DK, Van Tol HH, Damask SP, Little KY, Civelli O, et al. Dopamine receptor gene expression in the human medial temporal lobe. Neuropsychopharmacology 1994;10:239-248. [PubMed: 7945734]

Meririnne E, Kankaanpaa A, Seppala T. Rewarding properties of methylphenidate: sensitization by prior exposure to the drug and effects of dopamine D1- and D2-receptor antagonists. J Pharmacol Exp Therv 2001;298:539-550.

Missale C, Nash SR, Robinson SW, Jaber M, Caron MG. Dopamine receptors: from structure to function. Physiol Rev 1998;78:189-225. [PubMed: 9457173]

Mithani S, Martin-Iverson MT, Phillips AG, Fibiger HC. The effects of haloperidol on amphetamineand methylphenidate-induced conditioned place preferences and locomotor activity. Psychopharmacology (Berl) 1986;90:247-252. [PubMed: 3097706]

Mrzljak L, Bergson C, Pappy M, Huff R, Levenson R, Goldman-Rakic PS. Localization of dopamine D4 receptors in GABAergic neurons of the primate brain. Nature 1996;381:245-248. [PubMed: 8622768]

Newman-Tancredi A, Audinot-Bouchez V, Gobert A, Millan MJ. Noradrenaline and adrenaline are high affinity agonists at dopamine D4 receptors. Eur J Pharmacol 1997;319:379-383. [PubMed: 9042615]

Nielsen JA, Duda NJ, Mokler DJ, Moore KE. Self-administration of central stimulants by rats: a comparison of the effects of d-amphetamine, methylphenidate and McNeil 4612. Pharmacol Biochem Behav 1984;20:227-232. [PubMed: 6144109]

Parran TV Jr. Jasinski DR. Intravenous methylphenidate abuse. Prototype for prescription drug abuse. Arch Intern Med 1991;151:781-783. [PubMed: 1849397]

Paterson AD, Sunohara GA, Kennedy JL. Dopamine D4 receptor gene: novelty or nonsense. Neuropsychopharmacology 1999;21:3-16. [PubMed: 10379515]

Pum M, Carey RJ, Huston JP, Muller CP. Dissociating effects of cocaine and d-amphetamine on dopamine and serotonin in the perirhinal, entorhinal, and prefrontal cortex of freely moving rats. Psychopharmacology (Berl) 2007;193:375-390. [PubMed: 17468969]

Rezayof A, Zarrindast MR, Sahraei H, Haeri-Rohani AH. Involvement of dopamine D2 receptors of the central amygdala on the acquisition and expression of morphine-induced place preference in rat. Pharmacol Biochem Behav 2002;74:187-197. [PubMed: 12376167]

Ricci A, Bronzetti E, Fedele F, Ferrante F, Zaccheo D, Amenta F. Pharmacological characterization and autoradiographic localization of a putative dopamine D4 receptor in the heart. J Auton Pharmacol 1998;18:115-121. [PubMed: 9730266]

Robbins TW, Everitt BJ. Neurobehavioural mechanisms of reward and motivation. Curr Opin Neurobiol 1996;6:228-236. [PubMed: 8725965]

Rubinstein M, Phillips TJ, Bunzow JR, Falzone TL, Dziewczapolski G, Zhang G, et al. Mice lacking dopamine D4 receptors are supersensitive to ethanol, cocaine, and methamphetamine. Cell 1997;90:991-1001. [PubMed: 9323127]

Rush CR, Essman WD, Simpson CA, Baker RW. Reinforcing and subject-rated effects of methylphenidate and d-amphetamine in non-drug-abusing humans. J Clin Psychopharmacol 2001;21:273-286. [PubMed: 11386490]

Shimozato KW, Watanabe S. Concurrent evaluation of locomotor response to nevelty and propensity toward cocaine conditioned place preference in mice. J Neurosci Methods 2003;128:103-110. [PubMed: 12948553]

Sulzer D, Sonders MS, Poulsen NW, Galli A. Mechanisms of neurotransmitter release by amphetamines: a review. Prog Neurobiol 2005;75:406-433. [PubMed: 15955613] 
Swanson JM, Sunohara GA, Kennedy JL, Regino R, Fineberg E, Wigal T, et al. Association of the dopamine receptor D4 (DRD4) gene with a refined phenotype of attention deficit hyperactivity disorder (ADHD): a family-based approach. Mol Psychiatry 1998;3:38-41. [PubMed: 9491811]

Viggiano D, Ruocco LA, Sadile AG. Dopamine phenotype and behaviour in animal models: in relation to attention deficit hyperactivity disorder. Neurosci Biobehav Rev 2003;27:623-637. [PubMed: 14624807]

Volkow ND. Stimulant medications: how to minimize their reinforcing effects. Am J Psychiatry 2006;163:359-361. [PubMed: 16513852]

Volkow ND, Wang G, Fowler JS, Logan J, Gerasimov M, Maynard L, et al. Therapeutic doses of oral methylphenidate significantly increase extracellular dopamine in the human brain. J Neurosci 2001;21(RC121):1-5.

Volkow ND, Wang GJ, Fowler JS, Telang F, Maynard L, Logan J, et al. Evidence that methylphenidate enhances the saliency of a mathematical task by increasing dopamine in the human brain. Am J Psychiatry 2004;161:1173-1180. [PubMed: 15229048]

Wang E, Ding YC, Flodman P, Kidd JR, Kidd KK, Grady DL, et al. The genetic architecture of selection at the human dopamine receptor D4 (DRD4) gene locus. Am J Hum Genet 2004;74:931-944. [PubMed: 15077199]

Wedemeyer C, Goutman JD, Avale ME, Franchini LF, Rubinstein M, Calvo DJ. Functional activation by central monoamines of human dopamine $\mathrm{D}(4)$ receptor polymorphic variants coupled to GIRK channels in Xenopus oocytes. Eur J Pharmacol 2007;562:165-173. [PubMed: 17350612]

Williard RL, Middaugh LD, Zhu HJ, Patrick KS. Methylphenidate and its ethanol transesterification metabolite ethylphenidate: brain disposition, monoamine transporters and motor activity. Behav Pharmacol 2007;18:39-51. [PubMed: 17218796]

Wise RA, Hoffman DC. Localization of drug reward mechanisms by intracranial injections. Synapse 1992;10:247-263. [PubMed: 1557697]

Yokel RA, Wise RA. Amphetamine- type reinforcement by dopaminergic agonists in the rat. Psychopharmacology (Berl) 1978;58:289-296. [PubMed: 98800]

Zhang K, Tarazi FI, Davids E, Baldessarini RJ. Plasticity of dopamine D4 receptors in rat forebrain: temporal association with motor hyperactivity following neonatal 6-hydroxydopamine lesioning. Neuropsychopharmacology 2002;26:625-633. [PubMed: 11927187] 


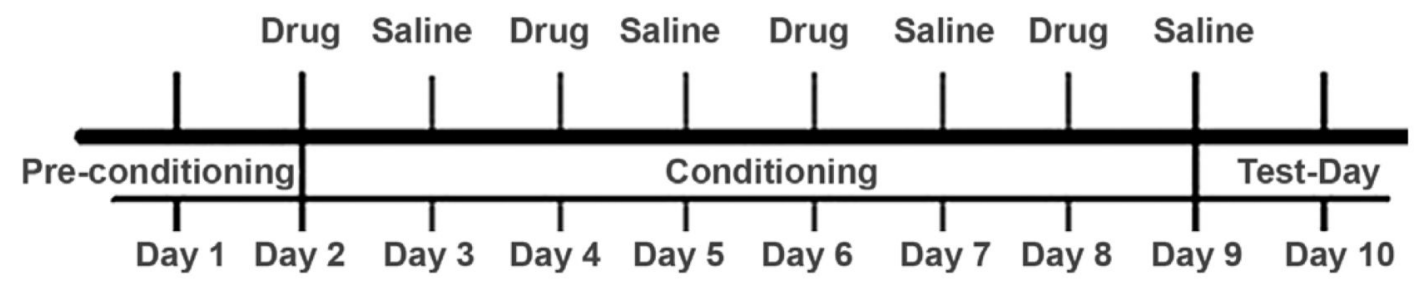

Figure 1.

Conditioned place preference timeline scheme. 


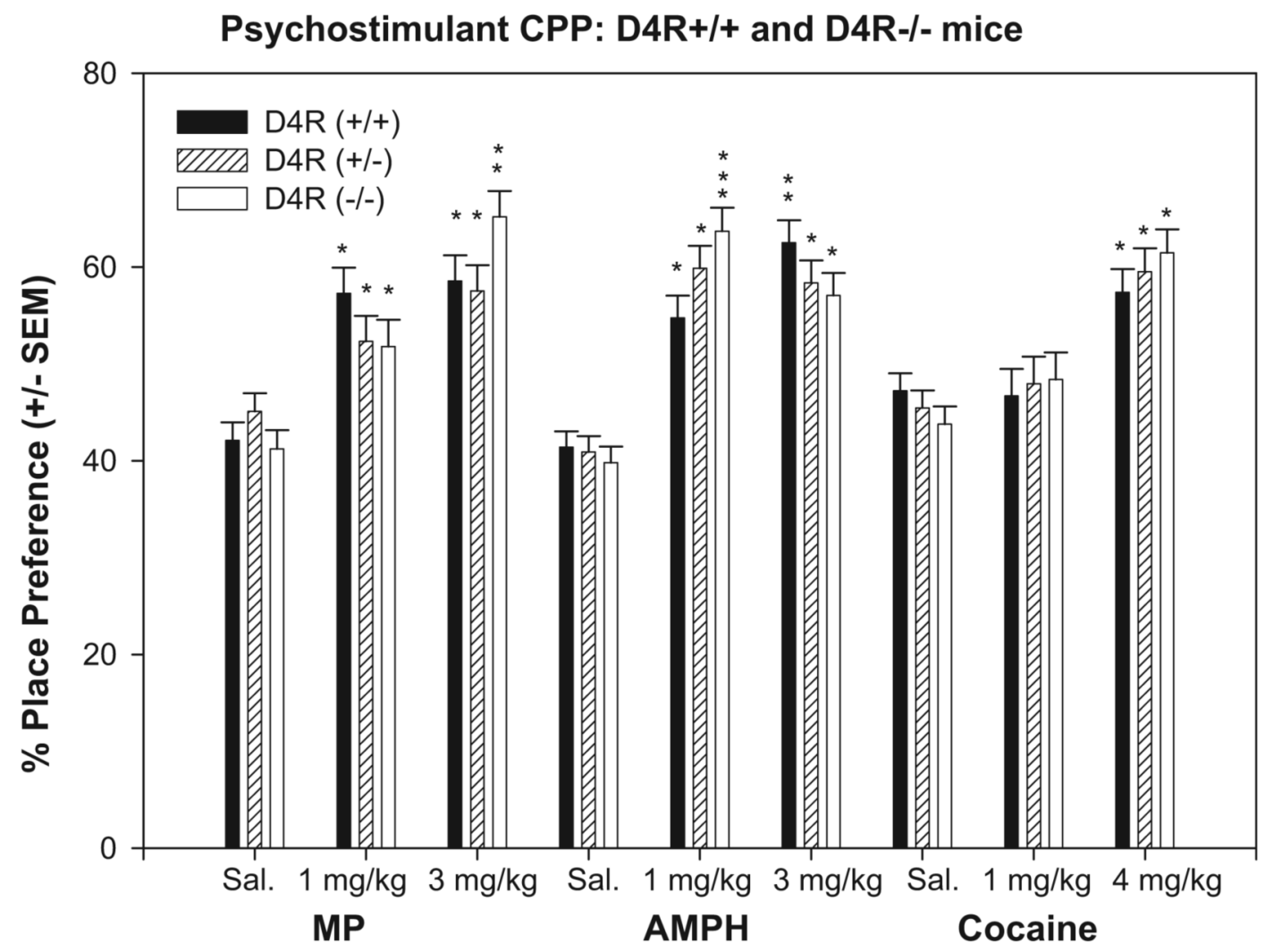

Figure 2.

Mean $( \pm$ SEM) place preference in the compartments paired to MP (1 or $3 \mathrm{mg} / \mathrm{kg}$, i.p.) and saline; AMPH (1 or $3 \mathrm{mg} / \mathrm{kg}$, i.p.) and saline; cocaine (1 or $4 \mathrm{mg} / \mathrm{kg}$, i.p.) and saline. Total \% preference equals the time spent in the drug-paired compartment (milliseconds) over the total time on both compartments on test day (15 minutes). *Indicates significant difference $(P<$ $0.01)$ in percentage time spent (CPP) between drug treatment and saline. $* *$ Indicates significant difference $(P<0.01)$ in CPP comparing treatments within genotype. ***Indicates significant differences $(P<0.001)$ in CPP between genotypes within treatment groups. 


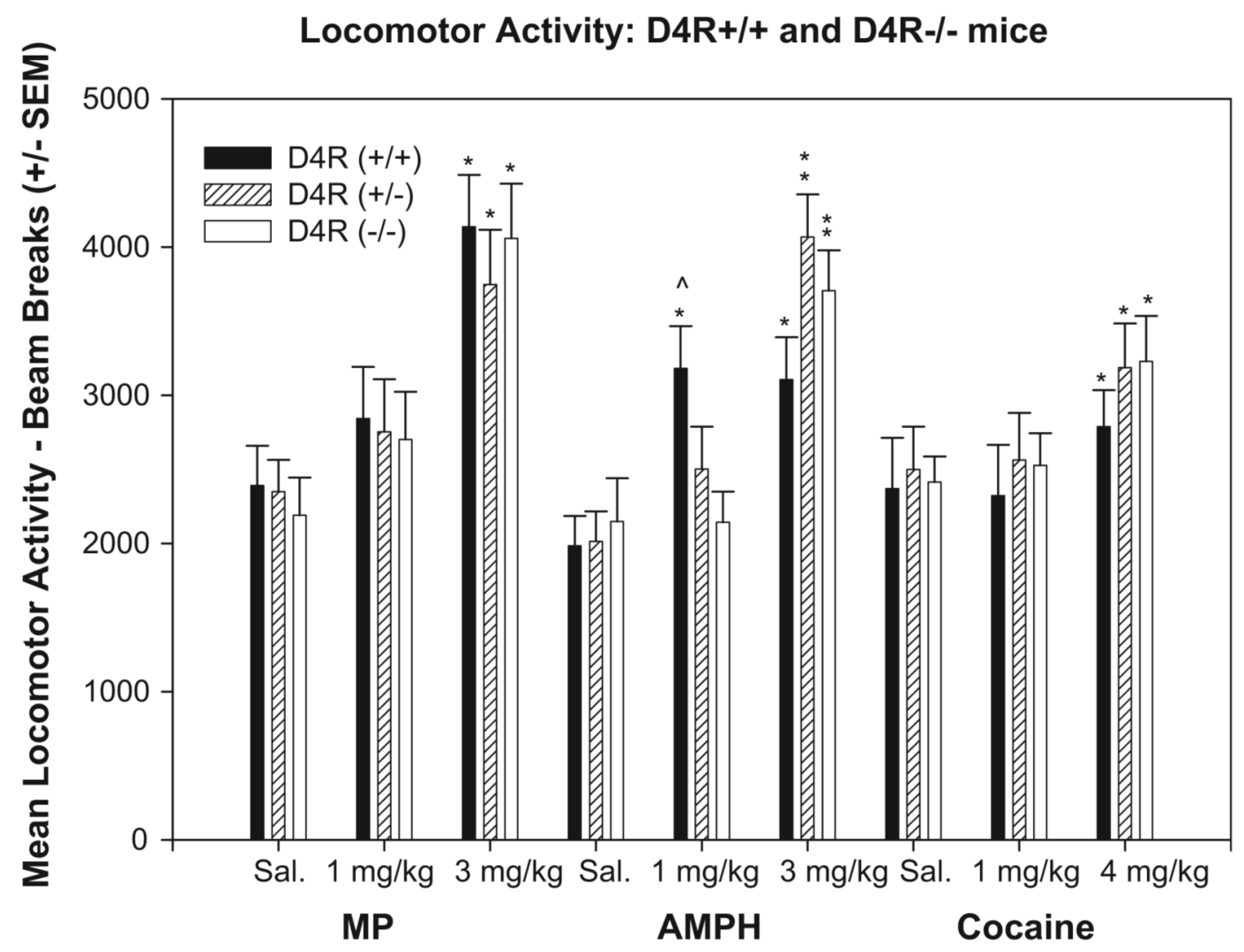

Figure 3.

Mean ( $($ SEM) locomotor activity: for saline, MP (1 or $3 \mathrm{mg} / \mathrm{kg}$, i.p.), AMPH (1 or $3 \mathrm{mg} / \mathrm{kg}$, i.p.) and cocaine (1 or $4 \mathrm{mg} / \mathrm{kg}$, i.p.). *Indicate significant difference in locomotor activity $(P<0.01)$ between treatment group and saline. **Indicates significant difference $(P<0.01)$ in locomotor activity comparing treatments within genotype across treatment groups. ${ }^{\wedge}$ Indicate significant difference $(P<0.01)$ in locomotor activity between genotype within treatment group - Significant difference in locomotor activity between the WT D4R $\mathrm{R}^{+/+}$and $\mathrm{KO}$ $\mathrm{D} 4 \mathrm{R}^{-1-}(\mathrm{t}=2.51 ; P<0.01)$. 